\title{
Research on Evaluation of Rural Highway Construction in Hebei Province
}

\author{
Guisheng Rao ${ }^{1}$, Limeng $\mathrm{Qi}^{1}$, Runqing Zhang ${ }^{1}$, and Li Deng ${ }^{2}$ \\ ${ }^{1}$ Agricultural University of Hebei, Hebei, P.R. China \\ ${ }^{2}$ Department of Economic and Management, Tangshan College, \\ Hebei, P.R. China
}

\begin{abstract}
Rural highway is the foundation of highway network construction and the important bridge for balancing urban and rural harmonious development. Rural highway has the basic, pilot and driving function to new rural construction. This paper took a sampling survey on 173 villages in Hebei Province. According to the 687 questionnaires, this paper set up an evaluation system of the rural highway construction in Hebei Province, using ten factors as effect variables (such as the degree of hardening the roads and the width of the roads). This article sorted selected indexes by AHP, and this paper gave scientific basis to improve policies on rural highway construction in Hebei Province through the sciencific evaluation of the rural highway construction in Hebei Province ${ }^{[1]}$.
\end{abstract}

Keywords: Rural highway of Hebei Province; Evaluation system; AHP.

\section{Introduction}

As the important public welfare in rural infrastructure, rural highway plays a special role in facilitating the travelling needs of rural residents, advancing the rural logistics flow, speeding up rural economic and cultural development, and building a socialist new countryside. In the 30 years since the reform and opening up, Hebei Province has made brilliant achievements in using of the favorable opportunities of implementing the proactive fiscal policy, accelerating infrastructure construction, and concentrating on a large scale in rural roads construction. The length of rural highway in Hebei Province was $30,300 \mathrm{~km}$ in 1978 , and reached $128,200 \mathrm{~km}$ by 2008 , by an increase of $323.52 \%$. The length of rural highway in Hebei Province was the 9th longest in China. Rapid development of rural roads played a very important role in advancing the economic and social development of Hebei province, especially the construction of new countryside. With the accelerated pace of rural highway construction and the improved grade of the highway, how to build the rural highway to adapt to the rural economic development and make the achievements of rural road construction benefit the broad masses is urgent. This study is concerning the problem. 


\section{Evaluation Model of Rural Roads Construction in Hebei}

\subsection{Sample Description}

During July and August in 2009, 173 villages were selected and investigated in the 11 prefecture-level cities of Hebei province (Table 1), through the summer investigation of the Agricultural University of Hebei, and 687 effective questionnaires were received. The survey covered a wide scope, involved all household types, with strong representation $^{[2]}$.

Table 1. Evaluation system of rural roads construction

\begin{tabular}{|c|c|c|}
\hline Target layer & $\begin{array}{l}\text { Primary } \\
\text { index }\end{array}$ & $\begin{array}{l}\text { Secondary } \\
\text { Index }\end{array}$ \\
\hline \multirow{11}{*}{$\begin{array}{l}\text { Evaluation System of } \\
\text { Rural Roads } \\
\text { Construction in } \\
\text { Hebei provence }\end{array}$} & \multirow{2}{*}{$\begin{array}{l}\text { Construction } \\
\text { quality of rural } \\
\text { Roads }\left(\mathrm{B}_{1}\right) \\
\end{array}$} & Pavement width $\left(\mathrm{C}_{1}\right)$ \\
\hline & & Sclerosis of roads $\left(C_{2}\right)$ \\
\hline & \multirow{3}{*}{$\begin{array}{l}\text { Facilities } \\
\text { in rural } \operatorname{roads}\left(\mathrm{B}_{2}\right)\end{array}$} & Highway lighting $\left(\mathrm{C}_{3}\right)$ \\
\hline & & $\begin{array}{l}\text { greening of } \\
\text { rural roads }\left(\mathrm{C}_{4}\right)\end{array}$ \\
\hline & & Trash clean-up facilities $\left(\mathrm{C}_{5}\right)$ \\
\hline & \multirow{3}{*}{$\begin{array}{l}\text { Management of rural } \\
\text { roads }\left(B_{3}\right)\end{array}$} & Villagers self-support $\left(\mathrm{C}_{6}\right)$ \\
\hline & & $\begin{array}{l}\text { Unified management by } \\
\text { counties and towns }\left(\mathrm{C}_{7}\right)\end{array}$ \\
\hline & & $\begin{array}{l}\text { Combining with the } \\
\text { former two factors }\left(\mathrm{C}_{8}\right)\end{array}$ \\
\hline & \multirow{3}{*}{$\begin{array}{l}\text { Rural roads } \\
\text { Investment }\left(\mathrm{B}_{4}\right)\end{array}$} & Government investment $\left(\mathrm{C}_{9}\right)$ \\
\hline & & $\begin{array}{l}\text { Villagers raise funds } \\
\text { by one project } \\
\text { one discussion system }\left(\mathrm{C}_{10}\right)\end{array}$ \\
\hline & & $\begin{array}{l}\text { Combining with the } \\
\text { former two factors }\left(C_{11}\right)\end{array}$ \\
\hline
\end{tabular}

\subsection{Model of Hierarchical Structure}

According to the issues of survey questionnaire, we divideed construction system of rural highway in Hebei into four major categories. They are the construction quality of rural highway, facilities construction of rural highway, management of rural highway and investment on rural highway. We put pavement width and sclerosis of roads as the secondary indexes of the construction quality of rural highway; put highway lighting, greening and trash clean-up facilities as the secondary indexes of facilities construction 
of rural highway; put villagers self-support, unified management by counties and towns and combining with the former two factors as the secondary indexes of management of rural highway; put government investment, raising funds by one project among villagers with one discussion system and combining with the former two factors as the secondary indexes of investment of rural highway. Considering the willingness of farmers totally, we invited 23 experts to rate each of the indices, and get final score of each indicator through summing of the average. Based on this formula, we established the AHP model which could evaluate the construction of rural highway in Hebei.

Due to the different levels of economic development in rural areas of Hebei, the effects of these four indicators are different to the development of rural highway in Hebei. Based on this, we construct hierarchical structure of the development of rural highway in Hebei.

\subsection{Build Judgement Matrix}

As the effects of each index are different to rural roads satisfaction of Hebei, we interviewed different experts and relevant administrative departments through questionnaire form and got digital data which are effect factors of highway construction in rural areas of Hebei (The weight of each factor), and then constructed the first order judgment matrix (Table 2) and the second order judgment matrix (Table3), researching the cognition of farmers on rural roads.

\subsection{Weight Calculation of Single Hierarchy and Consistency Test}

Eigenvalues and eigenvectors were calculated by AHP Software, the weight sorting results of each effect factor were listed in the table 2 and table 3 . The results of each matrix of the consistency test were listed in the bottom of each table.

From table 2 we can determine the effect size of various indicators in evaluation of highway construction in rural areas of Hebei, the result of operation was $\lambda_{\max }=4.181$,

Table 2. First order judgment matrix

\begin{tabular}{llllll}
\hline $\mathrm{A}$ & $\mathrm{B}_{1}$ & $\mathrm{~B}_{2}$ & $\mathrm{~B}_{3}$ & $\mathrm{~B}_{4}$ & Sort Weight \\
\hline $\mathrm{B}_{1}$ & 1 & 4 & 3 & $1 / 3$ & 0.269 \\
$\mathrm{~B}_{2}$ & $1 / 4$ & 1 & $1 / 3$ & $1 / 5$ & 0.068 \\
$\mathrm{~B}_{3}$ & $1 / 3$ & $1 / 3$ & 1 & $1 / 4$ & 0.134 \\
$\mathrm{~B}_{4}$ & 3 & 5 & 4 & 1 & 0.529 \\
\hline
\end{tabular}

Table 3. Second Order Judgment Matrix

\begin{tabular}{llll}
\hline $\mathrm{B}_{1}$ & $\mathrm{C}_{1}$ & $\mathrm{C}_{2}$ & Sort Weight \\
\hline $\mathrm{C}_{1}$ & 1 & $1 / 7$ & 0.125 \\
$\mathrm{C}_{2}$ & 7 & 1 & 0.875 \\
\hline
\end{tabular}


$\mathrm{CI}=0.060, \mathrm{RI}=0.900, \mathrm{CR}=0.067<0.1$, so the test of consistency passed. Results showed that the top one of weight sort was the investment on rural highway of Hebei, and it was 0.529 , playing an important part in this group. The second one of weight sort was the quality of rural roads construction, and it was 0.269 . The sum of two was 0.798 , the sum of other two was only 0.202 .

From table 3 , we can determine the contribution size of pavement width and sclerosis of roads in Hebei construction quality of rural highway, $\lambda_{\max }=2.000, \mathrm{CI}=0, \mathrm{RI}=0$, $\mathrm{CR}=0<0.1$, so the test of consistency passed. Results showed that the greatest impact on Hebei construction quality of rural roads is pavement width, which is much higher than the width of pavement.

Table 3. (Continuation Sheet 1)

\begin{tabular}{lllll}
\hline $\mathrm{B}_{2}$ & $\mathrm{C}_{3}$ & $\mathrm{C}_{4}$ & $\mathrm{C}_{5}$ & Sort Weight \\
\hline $\mathrm{C}_{3}$ & 1 & $1 / 3$ & 3 & 0.258 \\
$\mathrm{C}_{4}$ & 3 & 1 & 5 & 0.637 \\
$\mathrm{C}_{5}$ & $1 / 3$ & $1 / 5$ & 1 & 0.105 \\
\hline
\end{tabular}

From Table 3 (Continuation Sheet 1), we can determine the contribution size of highway lighting, greening of highway and trash clean-up facilities in Hebei facilities construction of rural highway, $\lambda_{\max }=3.039, \mathrm{CI}=0.019, \mathrm{RI}=0.580, \mathrm{CR}=0.033<0.1$, so the test of consistency passed. Results showed that the greatest impact in Hebei facilities construction of rural roads is greening of highway roads, and the weight sort is 0.637 ; and the next is highway lighting, and the weight sort is 0.258 ; the sum of two is 0.895 .

Table 3. (Continuation Sheet 2)

\begin{tabular}{lllll}
\hline $\mathrm{B}_{3}$ & $\mathrm{C}_{6}$ & $\mathrm{C}_{7}$ & $\mathrm{C}_{8}$ & Sort Weight \\
\hline $\mathrm{C}_{6}$ & 1 & 3 & $1 / 4$ & 0.226 \\
$\mathrm{C}_{7}$ & $1 / 3$ & 1 & $1 / 5$ & 0.101 \\
$\mathrm{C}_{8}$ & 4 & 5 & 1 & 0.674 \\
\hline
\end{tabular}

From Table 3(Continuation Sheet 2), we can determinehe the contribution size of villagers self-support, unified management by counties and towns and combining with the former two factors in management of rural highway, $\lambda_{\max }=3.086, \mathrm{CI}=0.043$, $\mathrm{RI}=0.580, \mathrm{CR}=0.074<0.1$, so the test of consistency passed. Results showed that the greatest impact on management of rural roads is townships management combining with villages, and the weight sort is 0.674 ; the sum of the other two is 0.327 .

From Table 3 (Continuation Sheet 3), we can determinehe the contribution size of government investment, raising funds by one project among villagers with one discussion system and combining with the former two factors in rural roads investment in the investment on the rural highway, $\lambda_{\max }=3.054, \mathrm{CI}=0.027, \mathrm{RI}=0.580, \mathrm{CR}=0.047<0.1$, so the test of consistency passed. Results showed that the greatest impact on the 
investment on rural highway is government investment combining with collecting money by villagers, and the weight sort is 0.691 ; the sum of the other two is 0.309 .

Table 3. (Continuation Sheet 3)

\begin{tabular}{lllll}
\hline $\mathrm{B}_{4}$ & $\mathrm{C}_{9}$ & $\mathrm{C}_{10}$ & $\mathrm{C}_{11}$ & Sort Weight \\
\hline $\mathrm{C}_{9}$ & 1 & 3 & $1 / 4$ & 0.218 \\
$\mathrm{C}_{10}$ & $1 / 3$ & 1 & $1 / 6$ & 0.091 \\
$\mathrm{C}_{11}$ & 4 & 6 & 1 & 0.691 \\
\hline
\end{tabular}

\subsection{Weight Calculation of Overall Hierarchy and Consistency Test}

$\mathrm{CI}=0.021, \mathrm{RI}=0.424, \mathrm{CR}=0.050<0.1$, so the test of consistency passed. From table 4 , we can arrive at the conclusion that the top three indexes are government investment, combining with collecting money by villagers and sclerosis of roads and government investment. Results showed that the investment on rural highway construction in Hebei should be financed mainly by government and farmers concerned sclerosis of rural roads most, both of them have become the most important factors in the evaluation system.

Table 4. Overall hierarchy

\begin{tabular}{llllll}
\hline A & B1 & B2 & B3 & B4 & Sort Weight \\
& 0.269 & 0.068 & 0.134 & 0.529 & \\
\hline C1 & 0.125 & & & & 0.034 \\
C2 & 0.875 & & & & 0.235 \\
C3 & & 0.258 & & 0.018 \\
C4 & & 0.637 & & & 0.043 \\
C5 & & 0.105 & & & 0.007 \\
C6 & & & 0.226 & & 0.030 \\
C7 & & & 0.101 & & 0.014 \\
C8 & & 0.674 & & 0.091 \\
C9 & & & 0.218 & 0.115 \\
C10 & & & & 0.091 & 0.048 \\
C11 & & & & 0.691 & 0.365 \\
\hline
\end{tabular}

\section{Conclusions and Recommendations}

(1) The position of greatest importance is source of investment in evaluation of highway construction in rural areas of Hebei, government investment accounted for a dominant position, rural roads are consistent with the characteristics of public goods. Therefore various places should be mainly based on financial allocations, supplemented by a variety of channels to raise, and adjust the expenditure of the local governments in time, rural roads construction should increase the proportion of public expenditure, introduce the mechanism of multiple investments ${ }^{[3]}$. 
(2) Under the premise of ensuring the rural highway construction funds, the quality of rural roads construction becomes the focus of evaluation of highway construction in rural areas of Hebei, sclerosis of roads has become the center of the quality of rural roads construction. After years of construction there are many rural roads paving with cement or asphalt pavement, but paving gravel broken stone or other materials is still very much, it has affected the living of local farmers and economic development. Therefore, government should increase the budget of rural roads construction, try to raise multiple funds, meantime act according to circumstances, on the basis of taking full advantage of original rural roads, improve the hardness of rural roads.

(3) Rural roads maintenance policy is imperfect, management system is sick, so the phenomenon of deficient maintenance is very universal. We suggest that township government be the main responsibility of rural roads maintenance, highway departments guide the implementation of industry.Routine maintenance of rural roads may be managed by village committee, major repair of pavement and pothole repair of asphalt pavement may entrust professional maintenance organizing ${ }^{[4]}$.

(4) With the raising of rural economy level, farmers pay more attention to the improvement of living environment. Therefore, greening of rural roads should manifest three features: leisure, culture and aesthetic, guide farmers through afforestation to improve their production and living conditions. Lighting facilities should be installed along rural roads to facilitate farmers travel at night. In addition to strengthening publicity, foster farmers the concept of protecting environment, enable farmers to designate dumping of solid waste in rural areas, and timely clean-up.

\section{Acknowledgement}

This paper is supported by The Social Science Fund of Hebei Province (HB10EYJ168), The Main Problems and Suggestions of Public Infrastructure Building in Hebei Natural Villages.

\section{References}

[1] Qi, L., Zhang, R., Zhao, X., Deng, L.: Analysis on The Regional Differences of Rural Infrastructure in Hebei. In: Proceedings of the 2009 International Conference on Public Economics and Management Xiamen, P. R. China, November 28-29 (2009)

[2] Yi, H.-m.: The Provision of Infrastructure and Farmers Demand-Evidence from 5 Province. China Soft Science, 11 (2008)

[3] Zhang, S.-1.: Research on the Peasants Desire of Supplying Rural Public Goods in Constructing New Rural Areas_—Based on a surrey of 644 farming households of Hebei. Rural Economy 4 (2008)

[4] Li, Z.: Research on Rural Infrastructure Investments- -An Case Study from Hebei Province. Agricultural University of HeBei (2007) 